\title{
Efficient Utilization of Paddy Straw and Sugarcane Bagasse through Vermicomposting and its Impact on Growth, Yield and Quality of Broccoli [Brassica oleracea (var.) italica]
}

\author{
Jasgeet Sofia Dhatt ${ }^{1}$, Kulbir Singh ${ }^{2}$, Harpreet Kaur ${ }^{1}$, S.S. Hundal ${ }^{1}$
}

10.18805/ag.D-5316

\begin{abstract}
Background: Broccoli [Brassica oleracea (var.) italica] is a cool season vegetable of family cruciferous, known as harigobi in Hindi. In modern agriculture, high doses of chemical fertilizers are used to maximize the crop production. Plenty of chemical fertilizers along with a small quantity of organic ones are being used to increase the yield which ultimately affects the health of soil. Due to excess use of chemical fertilizers a decline pattern is observed in soil fertility, therefore integrated nutrient management is an important demand of present era. Vermicompost application is an important forthcoming addition in this venture.

Methods: The research material comprised of seven treatments with three replications. Treatments included FYM (T1), Chemical fertilizer (T2), Paddy straw vermicompost (T3), Sugarcane bagasse vermicompost (T4), Paddy straw+Sugarcane bagasse vermicompost (T5), Vermicompost+Vermiwash (T6) and control (T7). The experiment was conducted considering the growth and yield parameters along with quality parameters.

Result: The results indicated that application of treatment T5 vermicompost was found to be the best treatment combination in terms of quality of broccoli. Thus, the study indicates that the vermicompost can be utilized effectively for sustainable crop production.

Key words: Broccoli, Fertilizer, Growth, Vermicompost, Quality, Yield.
\end{abstract}

\section{INTRODUCTION}

Broccoli is a cool season vegetable of family cruciferous, commonly known as harigobi in Hindi. It is either consumed raw as salad or cooked to prepare curries, soup and pickles. It is also known as "Crown of jewel nutrition" because it is rich in vitamins, proteins and minerals (Meena et al. 2017). Broccoli is of two types, heading and sprouting, sprouting broccoli is more popular in India. It was a rare cole crop in India but now gaining popularity in metropolitan's cities, reputed hotels and restaurants (Maurya et al. 2008). Broccoli possesses both antioxidant and anticarcinogenic properties and reduces the risk of prostate cancer by $45 \%$ (Nurhidayati et al. 2017; Singh et al. 2018). In modern agriculture, high doses of chemical fertilizers are used to maximize crop production. Plenty of chemical fertilizers along with small quantity of organic ones are being used to increase the yield which ultimately affects the health of soil as well as human (Meena et al. 2017). Due to excess use of chemical fertilizers a decline pattern is observed in soil fertility, therefore integrated nutrient management is an important demand of present era (Attigah et al. 2013). Vermicompost application is an important forthcoming addition in this venture. It maintains soil fertility and productivity. Organic manure plays a direct role in plant growth as a source of all necessary macro and micronutrient in available forms during mineralization and improving physical and chemical properties of soils (Chaterjee et al. 2005). Therefore, utilization of locally produced manures by vegetable production operations may increase crop yield with less use of chemical fertilizer. Hence, there is a need to substitute
${ }^{1}$ Department of Zoology, College of Basic Sciences and Humanities, Punjab Agricultural University, Ludhiana-141 004, Punjab, India. 2Department of Vegetable Science, College of Agriculture, Punjab Agricultural University, Ludhiana-141 004, Punjab, India.

Corresponding Author: Harpreet Kaur, Department of Zoology, College of Basic Sciences and Humanities, Punjab Agricultural University, Ludhiana-141 004, Punjab, India.

Email: harpreetimkaur@gmail.com

How to cite this article: Dhatt, J.S., Singh, K., Kaur, H. and Hundal, S.S. (2022). Efficient Utilization of Paddy Straw and Sugarcane Bagasse through Vermicomposting and its Impact on Growth, Yield and Quality of Broccoli [Brassica oleracea (var.) italica]. Agricultural Science Digest. DOI: 10.18805/ag.D-5316.

Submitted: 18-02-2021 Accepted: 29-11-2021 Online: 07-01-2021

the inorganic nutrient requirements with organic nutrient sources to enhance the production of plant with lower content of anti-nutritional factors.

\section{MATERIALS AND METHODS}

An investigation was carried out to study the effect of vermicompost on growth, yield and quality of broccoli at Vegetable seed production farm, Department of Vegetable Science, Punjab Agricultural University, Ludhiana, India, during season 2016-17 and 2017-18. Broccoli was grown in earthen pots of size 12 inches and later harvested for growth, yield and quality attributes. The treatments consisted the use of Farmyard manure in 50:50 ratio (T1), Chemical fertilizer $N(50): P(25): K(25)$ (T2), Paddy straw vermicompost 
Efficient Utilization of Paddy Straw and Sugarcane Bagasse through Vermicomposting and its Impact on Growth, Yield...

in 50:50 ratio (T3), Sugarcane bagasse vermicompost in 50:50 ratio (T4), Paddy straw + Sugarcane bagasse vermicompost in 50:50 ratio (T5), Vermicompost+Vermiwash in 50:50+1:10 ratio respectively (T6) and Control (soil) (T7). Each treatment was replicated three times. Various growth parameters such as plant height, leaf size, head size, number of auxiliary sprouts and yield parameters as gram per plant along with the qualitative analysis such as dry matter content, iron content, carotene content, total minerals, ascorbic acid and total glucosinolates were studied. Analysis of variance (2-way ANOVA) with randomized block design (RBD) was used for the statistical interpretation of the results.

\section{RESULTS AND DISCUSSION}

\section{Growth parameters}

Plant height $(\mathrm{cm})$ was recorded at 30,60 and 90 days after transplanting (DAT) and at harvest only while other parameters were recorded at the harvest only.

Table (1) indicates that the maximum height of plant was observed in treatment T2 i.e. $26.67 \mathrm{~cm}, 39.00 \mathrm{~cm}$ and $47.33 \mathrm{~cm}$ followed by treatment T5 i.e. $26.05 \mathrm{~cm}, 37.15 \mathrm{~cm}$ and $46.03 \mathrm{~cm}$ at 30,60 and 90 (DAT) and at harvest whereas the least plant height values were noted in treatment T7 i.e. $20.53 \mathrm{~cm}, 30.27 \mathrm{~cm}$ and $38.28 \mathrm{~cm}$. The increase in the plant height due to application of chemical fertilizer can be attributed to enhanced photosynthesis which resulted in more production of photosynthates and ultimately increases the plant height (Neethu et al. 2015; Dhakal et al. 2016; Singh et al. 2015; Singh et al. 2018).

The maximum increase in the leaf size was observed in T2 $\left(361.56 \mathrm{~cm}^{2}\right)$ followed by treatment T5 $\left(360.78 \mathrm{~cm}^{2}\right)$, T4 $\left(360.03 \mathrm{~cm}^{2}\right)$, T3 $\left(354.01 \mathrm{~cm}^{2}\right)$, T6 $\left(347.78 \mathrm{~cm}^{2}\right)$, T1 $\left(320.76 \mathrm{~cm}^{2}\right)$ and T7 $\left(314.53 \mathrm{~cm}^{2}\right)$ (Table 2). The present increase in the mean leaf size might be due to the application of organic fertilizer. The present increase in the leaf size due to the application of chemical fertilizer causes more production of cytokinin in the roots which is carried to leaves resulting in more cell division. Due to increase in number of cells, leaf expansion takes place and as a result the size of leaf increases (El-Helaly, 2012; Neethu et al. 2015; Singh et al. 2015; Dhakal et al. 2016).

The findings of the present study indicated that the head size of broccoli significantly increased with the addition of chemical fertilizer. Maximum head size was obtained in the treatment T2 $(15.11 \mathrm{~cm})$ followed by treatment T5 $(14.61$ $\mathrm{cm})$, treatment T4 $(14.43 \mathrm{~cm}), \mathrm{T} 3(13.74 \mathrm{~cm}), \mathrm{T} 6(12.21 \mathrm{~cm})$, T1 $(10.70 \mathrm{~cm})$ while the minimum head size was observed in T7 $(9.53 \mathrm{~cm}$ ) respectively (Table 2$)$. Increment in the head diameter was due to the reason that application of chemical fertilizer significantly increased the growth parameters and produced more plant metabolites which showed an obvious increase in head size (Singh et al. 2015; Dhakal et al. 2016; Singh et al. 2018).

The maximum numbers of sprouts were observed in the treatment T2 (10.00) followed by the T5 (8.66), T4 (8.17), T3 (7.87), T6 (7.00), T1 (6.00) as compared to T7 (4.67) (Table 2). The enhancing effect of fertilizer on number of auxialiary sprouts is supported by the findings of Yoldas et al. (2008) and Giri et al. (2013). Increase in number of auxiliary sprouts is related to increase in photosynthesis which stimulates leaf area increment, photosynthates production, meristemic activity, reflecting on the production of more organs (sprouts).

The maximum yield gram per plant i.e. $289.99 \mathrm{~g}$ was recorded in the treatment T2 followed by treatment T5 $(288.31 \mathrm{~g})$, treatment T4 $(287.04 \mathrm{~g})$, treatment T3 (281.35 $\mathrm{g})$, treatment T6 $(270.05 \mathrm{~g})$ and treatment T1 $(237.75 \mathrm{~g})$ respectively (Table 3 ). However, the minimum yield gram per plant was recorded in treatment T7 i.e. $217.98 \mathrm{~g}$. According to Quda and Mahadeen (2008) application of organic manures seemed to be less effective in increasing the yield than chemical fertilizers. The increase in yield attributes could be due to optimum vegetative growth of broccoli under application of chemical fertilizer which might assisted in more accumulation of nitrogen in the leaves, elevating the photosynthetic rate, resulting in more production of carbohydrates and thus increased the yield (Yoldas et al. 2008; El-Helaly, 2012; Neethu et al. 2015; Singh et al. 2015; Dhakal et al. 2016; Singh et al. 2018).

Table 1: Effect of vermicompost and vermiwash on height $(\mathrm{cm})$ of Broccoli.

\begin{tabular}{|c|c|c|c|c|c|c|c|c|c|}
\hline \multirow{3}{*}{ Treatments } & \multicolumn{9}{|c|}{ Plant height $(\mathrm{cm})$} \\
\hline & \multicolumn{3}{|c|}{30 DAT } & \multicolumn{3}{|c|}{60 DAT } & \multicolumn{3}{|c|}{90 DAT } \\
\hline & $2016-17$ & $2017-18$ & Mean & $2016-17$ & $2017-18$ & Mean & 2016-17 & $2017-18$ & Mean \\
\hline T1-FYM & 21.17 & 22.37 & 22.27 & 31.13 & 32.03 & 31.58 & 39.23 & 40.00 & 39.62 \\
\hline T2-Chemical fertilizer & 26.10 & 27.23 & 26.67 & 37.20 & 40.80 & 39.00 & 45.43 & 49.23 & 47.33 \\
\hline T3-Paddy straw Vermicompost & 23.53 & 23.80 & 23.67 & 35.00 & 35.60 & 35.30 & 42.77 & 43.43 & 43.10 \\
\hline T4-Sugarcane bagasse Vermicompost & 24.20 & 25.07 & 24.64 & 36.13 & 36.37 & 36.25 & 43.00 & 45.47 & 44.24 \\
\hline $\begin{array}{l}\text { T5- Paddy straw+sugarcane bagasse } \\
\text { Vermicompost }\end{array}$ & 25.27 & 26.83 & 26.05 & 36.43 & 37.86 & 37.15 & 44.40 & 47.67 & 46.03 \\
\hline T6-Vermicompost +Vermiwash & 22.27 & 22.37 & 22.32 & 33.27 & 34.00 & 33.63 & 41.73 & 40.97 & 41.35 \\
\hline T7-Control & 20.47 & 20.60 & 20.53 & 30.13 & 30.40 & 30.27 & 38.80 & 37.77 & 38.28 \\
\hline LSD $(p=0.05)$ & NS & NS & NS & NS & 5.50 & 3.93 & NS & 4.52 & 3.51 \\
\hline
\end{tabular}

(DAT-Days after transplanting). 


\section{Quality parameters}

The data analysis revealed that maximum dry matter $(9.29 \%)$ was recorded in the treatment $\mathrm{T} 5$ which was statistically at par with the treatment T4 $(9.09 \%)$ respectively. However, the dry matter of $8.69 \%$ was recorded in the treatment T3 followed by treatment T6 $(7.96 \%)$, treatment T2 $(7.88 \%)$ and treatment T1 $(5.62 \%)$ whereas the minimum dry matter was noticed in the treatment T7 $(4.62 \%)$ respectively (Table 4 ). The increase in dry matter weight could be due to more vegetative growth of plant. Application of vermicompost stimulates the leaf size, expansion in leaf size promotes the process of photosynthesis and accumulates more photosythates which in turn increases the dry matter content of plants (Singh et al. 2018). Similar finding has been reported by Azarmi et al. (2008) in tomato with increase in dry matter via application of vermicompost.

However, the results of the present study revealed that the carotene content were in the order PS+SBVC $(14.60$ $\mathrm{mg} / 100 \mathrm{~g})>$ SBVC $(14.01 \mathrm{mg} / 100 \mathrm{~g})>$ VCVW $(13.04 \mathrm{mg} /$ $100 \mathrm{~g})>$ PSVC $(13.02 \mathrm{mg} / 100 \mathrm{~g})>$ CF $(10.89 \mathrm{mg} / 100 \mathrm{~g})>$ FYM (10.25 mg/100 g) as compare to control (Table 4). The result is in consistence with the findings of Yadav et al. (2016); Mauriya et al. (2018) and Singh et al. (2018).

In addition, the maximum ascorbic acid content (107.14 $\mathrm{mg} / 100 \mathrm{~g}$ ) was recorded in the treatment T5 followed by the treatment T4 $(106.06 \mathrm{mg} / 100 \mathrm{~g})$, treatment T3 $(102.96 \mathrm{mg} /$ $100 \mathrm{~g})$, treatment T6 $(101.25 \mathrm{mg} / 100 \mathrm{~g})$, treatment T2 $(100.15 \mathrm{mg} / 100 \mathrm{~g})$ and treatment T1 $(95.95 \mathrm{mg} / 100 \mathrm{~g})$ respectively while the minimum ascorbic acid level of 94.16 $\mathrm{mg} / 100 \mathrm{~g}$ was recorded in treatment T7 (Table 5). The increase in ascorbic acid content by the application of vermicompost may be attributed to increased availability of nutrients in the soil that might lead to synthesis and accumulation of more photosynthates which mobilized the biosynthesis of ascorbic acid (Mal et al. 2015). Dhakal et al. (2016) reported that the application of vermicompost and farm yard manure increases the ascorbic acid content in broccoli. The results are in consistence with the finding of Meena et al. (2017) who reported an increase in ascorbic acid content with the application of organic manures and biofertlizer on quality of broccoli.

Glucosinolates are known for their health benefits especially due to anticarcinogenic properties and therefore its higher content in broccoli is desirable. The present findings showed that vermicompost had significant effect on glucosinolates concentrations. The maximum total glucosinolate content $(57.71 \mu \mathrm{mol} / \mathrm{g})$ was noted with application of treatment T5 which was statistically at par with the treatment T4 $(57.34 \mu \mathrm{mol} / \mathrm{g})$. The application of the treatment T3 showed total glucosinolate content of 55.66 $\mu \mathrm{mol} / \mathrm{g}$ followed by treatment T6 $(54.17 \mu \mathrm{mol} / \mathrm{g})$, treatment T2 $(52.49 \mu \mathrm{mol} / \mathrm{g})$, treatment T1 $(49.95 \mu \mathrm{mol} / \mathrm{g})$ and treatment T7 $(47.46 \mu \mathrm{mol} / \mathrm{g})$ respectively (Table 5). These results supported the findings of Naguib et al. (2012); Rosa and Rodrigues, (2001) who reported an increase in the total glucosinolates content with the application of organic fertilizer in broccoli.

Table 2: Effect of vermicompost and vermiwash on leaf size $\left(\mathrm{cm}^{2}\right)$, head size $(\mathrm{cm})$ and no. of sprouts of Broccoli.

\begin{tabular}{|c|c|c|c|c|c|c|c|c|c|}
\hline \multirow{2}{*}{ Treatments } & \multicolumn{3}{|c|}{ Leaf size $\left(\mathrm{cm}^{2}\right)$} & \multicolumn{3}{|c|}{ Head size $(\mathrm{cm})$} & \multicolumn{3}{|c|}{ No. of sprouts } \\
\hline & $2016-17$ & $2017-18$ & Mean & $2016-17$ & $2017-18$ & Mean & 2016-17 & $2017-18$ & Mean \\
\hline T1-FYM & 321.76 & 319.76 & 320.76 & 11.22 & 10.18 & 10.70 & 5.67 & 6.33 & 6.00 \\
\hline T2-Chemical fertilizer & 360.86 & 362.27 & 361.56 & 14.90 & 15.31 & 15.11 & 10.66 & 9.33 & 10.00 \\
\hline T3-Paddy straw vermicompost & 354.16 & 353.87 & 354.01 & 13.17 & 14.31 & 13.74 & 7.67 & 8.07 & 7.87 \\
\hline T4-Sugarcane bagasse vermicompost & 359.86 & 360.20 & 360.03 & 13.92 & 14.95 & 14.43 & 8.33 & 8.00 & 8.17 \\
\hline $\begin{array}{l}\text { T5- Paddy straw+sugarcane bagasse } \\
\text { Vermicompost }\end{array}$ & 360.53 & 361.03 & 360.78 & 14.10 & 15.11 & 14.61 & 8.67 & 8.66 & 8.66 \\
\hline T6-Vermicompost+vermiwash & 348.16 & 346.80 & 347.48 & 12.07 & 12.34 & 12.21 & 7.33 & 6.66 & 7.00 \\
\hline T7-Control & 315.26 & 313.80 & 314.53 & 10.18 & 8.88 & 9.53 & 5.33 & 4.00 & 4.67 \\
\hline LSD $(p=0.05)$ & & & & NS & 3.72 & 2.36 & 3.03 & 2.14 & 1.84 \\
\hline
\end{tabular}

Table 3: Effect of vermicompost and vermiwash on yield gram/plant of broccoli.

\begin{tabular}{|c|c|c|c|}
\hline \multirow{2}{*}{ Treatments } & \multicolumn{3}{|c|}{ Yield (g/plant) } \\
\hline & $2016-17$ & $2017-18$ & Mean \\
\hline T1-FYM & 237.63 & 237.88 & 237.75 \\
\hline T2-Chemical fertilizer & 288.59 & 291.39 & 289.99 \\
\hline T3-Paddy straw vermicompost & 279.13 & 283.56 & 281.35 \\
\hline T4-Sugarcane bagasse vermicompost & 268.87 & 287.21 & 287.04 \\
\hline T5-Paddy straw+sugarcane bagasse vermicompost & 287.41 & 289.21 & 288.31 \\
\hline T6-Vermicompost+vermiwash & 272.10 & 268.01 & 270.05 \\
\hline T7-Control & 218.72 & 217.24 & 217.98 \\
\hline $\operatorname{LSD}(p=0.05)$ & 11.49 & 11.82 & 7.60 \\
\hline
\end{tabular}


Efficient Utilization of Paddy Straw and Sugarcane Bagasse through Vermicomposting and its Impact on Growth, Yield...

Table 4: Effect of vermicompost and vermiwash on dry matter (\%) and carotene content (mg/100 gm) of Broccoli.

\begin{tabular}{|c|c|c|c|c|c|c|}
\hline \multirow{2}{*}{ Treatments } & \multicolumn{3}{|c|}{ Dry matter \% } & \multicolumn{3}{|c|}{ Carotene content $(\mathrm{mg} / 100 \mathrm{gm})$} \\
\hline & $2016-17$ & $2017-18$ & Mean & $2016-17$ & $2017-18$ & Mean \\
\hline T1- FYM & 6.03 & 5.20 & 5.62 & 11.10 & 9.39 & 10.25 \\
\hline T2- Chemical fertilizer & 7.36 & 8.39 & 7.88 & 12.32 & 9.46 & 10.89 \\
\hline T3- Paddy straw vermicompost & 8.10 & 9.28 & 8.69 & 13.50 & 12.53 & 13.02 \\
\hline T4- Sugarcane bagasse vermicompost & 8.63 & 9.54 & 9.09 & 14.02 & 13.99 & 14.01 \\
\hline T5- Paddy straw+sugarcane bagasse vermicompost & 8.77 & 9.82 & 9.29 & 14.14 & 15.05 & 14.60 \\
\hline T6- Vermicompost+vermiwash & 7.79 & 8.13 & 7.96 & 13.03 & 13.04 & 13.04 \\
\hline T7- Control & 5.45 & 3.78 & 4.62 & 10.19 & 8.10 & 9.15 \\
\hline LSD $(p=0.05)$ & NS & 1.94 & 1.48 & NS & 2.84 & 1.86 \\
\hline
\end{tabular}

Table 5: Effect of vermicompost and vermiwash on ascorbic acid (mg/100 gm) and total glucosinolate content $(\mu \mathrm{mol} / \mathrm{g})$ of Broccoli.

\begin{tabular}{|c|c|c|c|c|c|c|}
\hline \multirow[t]{2}{*}{ Treatments } & \multicolumn{3}{|c|}{$\begin{array}{l}\text { Ascorbic acid } \\
(\mathrm{mg} / 100 \mathrm{~g})\end{array}$} & \multicolumn{3}{|c|}{$\begin{array}{l}\text { Total glucosinolate content } \\
(\mu \mathrm{mol} / \mathrm{g})\end{array}$} \\
\hline & $2016-17$ & $2017-18$ & Mean & $2016-17$ & $2017-18$ & Mean \\
\hline T1-FYM & 95.92 & 96.03 & 95.98 & 49.59 & 50.31 & 49.95 \\
\hline T2-Chemical fertilizer & 99.24 & 101.06 & 100.15 & 51.55 & 53.42 & 52.49 \\
\hline T3-Paddy straw vermicompost & 102.58 & 103.35 & 102.96 & 55.18 & 56.13 & 55.66 \\
\hline T4-Sugarcane bagasse vermicompost & 105.15 & 106.97 & 106.06 & 56.49 & 58.18 & 57.34 \\
\hline T5-Paddy straw+sugarcane vermicompost & 106.07 & 108.20 & 107.14 & 56.89 & 58.53 & 57.71 \\
\hline T6-Vermicompost+vermiwash & 100.36 & 102.13 & 101.25 & 53.32 & 55.01 & 54.17 \\
\hline T7-Control & 95.34 & 92.97 & 94.16 & 48.65 & 46.27 & 47.46 \\
\hline LSD $(p=0.05)$ & NS & NS & NS & NS & NS & NS \\
\hline
\end{tabular}

Thus, the present study revealed that the broccoli plants when grown in soil amended with vermicompost showed better results in terms of quality parameters. Variations in plant growth, yield and quality might be due to the availability of nutrients through application of inorganic fertilizers and organic manure enhances soil aggregation, aeration, water holding capacity (Arisha et al 2003, Devi et al 2003, Shapla et al 2014). Meena et al (2017) reported that the quality of broccoli crop improved with the effect of organic manures and bio fertilizer and noted the maximum ascorbic acid content $(90.50 \mathrm{mg} / 100$ g) in T8 (RDF25\%+Vermicompost $50 \%$ +azotobacter $50 \%+$ azotobecter $25 \%$ ). Effect of vermicompost and other organic fertilizers due to the better availability of soil nutrients improved the soil chemical and physical properties thereby producing healthy plants (Stewart et al. 2005; Ouda and Mahadeen (2008); Maurya et al. 2008 and Singh and Pandey, 2010). Thus, our results are in correlation with the findings of many researchers (Ahirwar and Hussain, 2015 in vegetable crops; Mal et al. 2015 on sprouting broccoli; Dhakal et al. 2016 on broccoli; Esakkaimmal et al. 2015 on dolichous lab lab.; Yadav et al. 2016 on broccoli; Mauriya et al. 2018 on broccoli; Meena et al. 2017 on okra; Singh et al. 2018 on [Brassica oleracea (var.) italica]. Moreover, broccoli prepared by the application of vermicompost is expected to be healthier compared to those prepared with chemical fertilizers.

\section{CONCLUSION}

The study revealed that the integration of chemical fertilizers had shown an enhancing effect on growth and yield of broccoli whereas the vermicompost enhanced the overall quality of broccoli. On the basis of results, it is concluded that the vermicompost prepared from the test substrates viz. paddy straw + sugarcane bagasse $(P S+S B)$ revealed beneficial outcomes with improved effects on the quality attributes of Broccoli. Thus, the study indicates that the vermicompost can be utilized effectively for sustainable crop production.

\section{ACKNOWLEDGEMENT}

The authors are thankful to the Head, Department of Vegetable Science, College of Agriculture, Department of Zoology, College of Basic Sciences and Humanities, Punjab Agricultural University for providing all the necessary facilities required to perform this research work.

\section{Conflict of interest: None.}

\section{REFERENCES}

Ahirwar, C.A. and Azad, H. (2015). Effect of vermicompost on growth, yield and quality of vegetable crops. Int. J. Appl. Pure. Sci. Agri. 1: 15-18.

Arisha, H.M.E., Gad, A.A. and Younes, S.E. (2003). Response of some pepper cultivars to organic and mineral nitrogen fertilizer under sandy soil conditions. Zagazig. J. Agric. Res. 30: 1875-99. 
Attigah, A.S., Asiedu, E.K., Agyarko, K. and Dapaah, H.K. (2013). Growth and yield of okra (Abelmoschus esculentus L.) as affected by organic and inorganic fertilizers ARPN: J. Agri. Biol. Sci. 8: 766-70.

Azarmi, R., Ziveh, P.S. and Satari, M.R. (2008). Effect of vermicompost on growth, yield and nutrition status of tomato (Lycopersicum esculentum). Pak. J. Biol Sci. 11(14): 1797-802.

Chaterjee, B., Ghanti, P., Thapa, U. and Tripathy, P. (2005). Effect of organic nutrition in sprouting broccoli. Vegetable Sci. 33: $51-54$.

Devi, H.J., Maity and Paria, N.C. (2003). Effect of different sources of nitrogen on yield and economics of cabbage. Environ Ecol. 21: 878-80.

Dhakal, M., Shakya, S.M., Bhattarai, S. (2016). Yield and quality of broccoli, affected by nitrogen and farm yard manure in Chitwan, Nepal. J Plant Heal. 1: 1-8.

El-Helaly, M.A. (2012). Effect of nitrogen fertilization rates and potassium sources on broccoli yield, quality and storability. Res J. Agric. and Biol. Sci. 8: 385-94.

Esakkiammal, B., Lakshmibai, L. and Sornalatha, S. (2015). Studies on the Combined effect of Vermicompost and Vermiwash prepared from organic wastes by earthworms on the growth and yield parameters of dolichous lab lab. Asian J. Pharma Sci. Technol. 5: 246-52.

Giri, R.K., Sharma, M.D., Shakya, S.M., Yubak, D.G.C. and Kandel, T.P. (2013). Growth and yield responses of broccoli cultivars to different rates of nitrogen in western Chitwan, Nepal Agric. Sci. 4: 8-12.

Mal, D., Chatterjee, R. and Nimbalkar, K.H. (2015). Effect of vermicompost and inorganic fertilizers on growth, yield and quality of sprouting broccoli [Brassica oleracea (L.) var. italica Plenck]. Int. J. Bioresourc Stress Management. 5: 507-512.

Mauriya, S.K., Dwivedi, D.H., Lalita, K. and Kumar, S. (2018). Influence of organic, inorganic fertilizers and micronutrients on growth of broccoli. J. Pharmacognosy Phytochem. 7: 2107-09.

Maurya, A.K., Singh, M.P., Srivastava, B.K., Singh, Y.V., Singh, S. and Singh, P.K. (2008). Effect of organic manures and inorganic fertilizers on growth characters yield and economics of sprouting broccoli cv Fiesta. Indian J. Horticulture. 65: 116-118.

Meena, K., Ram, R.B., Meena, M.L., Meena, J.K. and Meena, D.C. (2017). Effect of Organic Manures and Bio-Fertilizers on Growth, Yield and Quality of Broccoli [Brassica oleracea (var.) italica Plenck] cv. KTS-1. Chem. Sci. Rev. Lett. 6: 2153-2158.
Meena, V.K., Dubey, A.K., Jain, V.K., Tiwari, A. and Negi, P. (2017) Effect of plant growth promoters on flowering and fruiting attributes of okra (Abelmoschus esculentus L). Crop Res. 52: $37-40$

Naguib, A.M., El-Baz, F.K., Salama, Z.A., Hanaa, H., Ali, H.F. and Gaafar, A.A. (2012). Enhancement of phenolics, flavonoids and glucosinolates of Broccoli (Brassica olaracea, var. Italica) as antioxidants in response to organic and bioorganic fertilizers J. Saudi Society Agric. Sci. 11: 135-142.

Neethu, T.M., Tripathi, S.M., Narwade, A.V. and Sreeganesh, S. (2015). Effect of $\mathrm{N}$ and $\mathrm{P}$ levels on growth and yield parameters of broccoli (Brassica oleracea var. italica) under south Gujarat soil conditions. Int. J. Trop. Agri. 33: 913-917.

Nurhidayati, N., Machfudz, M. and Murwani, I. (2017). Direct and Residual Effect of Various Vermicompost on Yield and Quality of Broccoli J. Appl. Sci. Res. 13: 30-37.

Ouda, B.A. and Mahadeen, A.Y. (2008). Effect of fertilizers on growth, yield, yield components, quality and certain nutrient contents in broccoli (Brassica oleracea). Int J Agri Biol. 10: 627-32.

Rosa, E.A.S. and Rodrigues, A.S. (2001). Total and individual glucosinolate content in 11 broccoli cultivars grown in early and late seasons. Hort. Sci. 36: 56-59.

Shapla, S.A., Hussain, M.A., Mandal, M.S.H, Mehraj, H. and Jamal, A.F.M. (2014). Growth and yield of broccoli (Brassica oleracea var. italica) to different organic manures. Int. J. Sustain Crop Prod. 9: 29-32.

Singh, G., Sarvanan, S., Kerketta, A. and Rajesh, J. (2018). Effect of Organic Manures and Inorganic Fertilizers on Plant Growth, Yield and Flower Bud Quality of Broccoli (Brassica oleracea var. Italica) cv- Green Magic, Int. J. Pure App. Biosci. 6: 1338-42.

Singh, M.K., Chand, T., Kumar, M., Singh, K.V., Lodhi, S.K., Singh, V.P. and Sirohi, V.K. (2015b). Response of Different Doses of NPK and Boron on Growth and Yield of Broccoli (Brassica oleracea $L$. var. italica). Int J Bioresourc Stress Management. 6: 108-112.

Singh, P.K. and Pandey, M. (2010). Study the effect of integrated nutrient management on yield and nutrient uptake in cabbage. Indian J. Hill Farming. 23: 39-41.

Stewart, M.W., Dibb, W.D., Johnston, E.A. and Smyth, J.T. (2005). The Contribution of Commercial Fertilizer Nutrients to Food Production. Agron J. 97: 1-6.

Yadav, L.P., Singh, A. and Malhotra, S.K. (2016). Growth, yield and quality response of organic broccoli to intercrops and crop geometry Indian J. Hort. 73: 376-82.

Yoldas, F., Ceylan, S., Yagmur, B. and Mordogan, N. (2008). Effects of Nitrogen Fertilizer on Yield Quality and Nutrient Content in Broccoli. J. Plant Nutr. 31: 1333-43. 